\title{
Det normalas lockelse - berättelser från marginalen
}

HARRIET STRANDELL, ILSE JULKUNEN \& KATRI LAMMINEN

\begin{abstract}
Marginaliseringsdiskursen har bitit sig fast i den offentliga debatten, men hur ser ungdomar som definierats som marginaliserade själva på sina liv? I denna artikel analyseras ungdomars egna berättelser utgående från hur de konstruerar sin identitet. Det är framför allt spänningen mellan normalbiografi och problemidentitet vi tagit fastapå.
\end{abstract}

\section{Inledning}

"Jag hoppas att jag om fem år har hyreslägenhet, körkort, bil och pojkvän, och jobb och studieplats. "Denna förhoppning uttrycktes av en ung flicka inom barnskyddet ${ }^{1}$ som intervjuades i ett forskningsprojekt, där ett aktiveringsprojekt för 17-21-åriga ungdomar inom barnskyddet i Helsingfors (det sk. HELSA-projektet) utvärderades. Projektets syfte var att förebygga marginalisering och hjälpa ungdomarna till att bättre bemästra sitt liv. Projektets verksamhet och resultat utvärderades under åren 1996-1999².

Hur konstruerar de ungdomar som definierats som marginaliserade det som

Harriet Strandell, Docent, Universitetslektor i sociologi, Helsingfors universitet, Sociologiska institutionen

Ilse Julkunen, Pol dr, Utvecklingschef , Stakes

Katri Lamminen, Forskare, pol.mag., doktorand, Svenska social- och kommunalhögskolan vid Helsingfors universitet de riskerar att marginaliseras från? Hurudant borde deras liv vara för att det skulle passa in i den ram som "vi« (normalsamhället) skapat? När vi tänker på ungdomarnas marginalitet tänker vi inte i första hand på de särskilda livserfarenheter som lett till att barnskyddet har ingripit och på grund av vilka ungdomarna har särskilda svårigheter att komma in i arbetslivet. Inom ramen för denna artikel diskuteras ej i vilken mån ungdomarna löper faktisk risk för att marginaliseras ${ }^{3}$. Hur man förhåller sig till ungdomarna tror vi har en avgörande inverkan på deras inställning till sitt eget liv och sina egna möjligheter (jfr Swärd 1999). Som kli-

1 I Sverige motsvaras termen barnskydd av social barnavård.

2 Evalueringens resultat har publicerats i Julkunen, Strandell, Kangas (2000).

3 Detta har vi skrivit om i evalueringsprojektets slutrapport (Julkunen, Strandell, Kangas 2000) 
enter inom barnskyddet har de varit och är alltjämt föremål för socialmyndigheternas normaliserande interventioner. Arbetslösa ungdomar med barnskyddsbakgrund kontrolleras i hög grad av institutioner, och de är föremål för en allt starkare statsintervention (Puuronen 1997). Exempel på interventioner är identifierandet och påtalandet av riskfaktorer, stödåtgärder inom öppna vården, omhändertagande, vård i fosterhem, eftervård, serviceboende. I och genom interventionerna definieras ungdomarna som marginaliserade. Marginaliseringsdiskursen har präntats in i den offentliga debatten och bitit sig fast i politikernas, myndigheternas, fältarbetarnas och forskarnas språkbruk (Helne 1994, 32-33).

\section{Från ung till vuxen}

De unga vi har intervjuat är objekt för normaliserande interventioner inte enbart i egenskap av klienter inom barnskyddet, utan också för att de är unga. Att bli vuxen betraktas av samhället som ett övergångsskede. Övergången från ung till vuxen är institutionaliserad; de mest centrala institutionerna är att komma in i arbetslivet, att flytta till eget och att bilda familj (Wyn \& White 1997). Johanna Wyn och Rob White (ibid., 94-98) fäster uppmärksamhet vid övergångsbegreppets normativitet och linearitet. Begreppet utgår från ett förhandsantagande om en enkel övergång från ett mellanskede av ungdomstillstånd till ett färdigt vuxenliv. I verkligheten är övergångarna både mångdimensionella och går i flera olika riktningar. Övergångsskedet får vanligen uppmärksamhet endast i de fall då övergången inte följer det utstakade förloppet (Griffin 1997).
För ungdomar inom barnskyddet får den institutionella övergången sina egna särdrag. Detta gäller speciellt dem som bor i anstalter, från vilka de flyttar ut efter att ha uppnått en viss ålder. För att underlätta och administrera dessa övergångar och de problem som uppstått i dem har samhället skapat speciella institutioner, såsom serviceboende och eftervård. Socialarbetaren håller genom dessa kontakt med den unga en viss tid efter han eller hon har flyttat ut från anstalten. Till dessa specialinstitutioner hör även HELSA och liknande projekt och program som riktar sig till just denna målgrupp.

I och med att övergången till vuxenlivet blivit mera komplex finns det i dagens samhälle en social beställning på specialinstitutioner. I Finland liksom i de övriga nordiska länderna började man fästa ny uppmärksamhet vid övergången till vuxenlivet under 1990-talet då massarbetslösheten förändrade levnadssituationen och utbildningens betydelse för att säkra övergången till arbetslivet försvagades. Övergången från skola till arbetsliv har blivit mera osäker och inrymmer ofta flera avbrott (Bynner 1997; Wyn \& White 1997; Fauske 1996). I europeiskt perspektiv talar man om jo-jo övergångar (Walther et al 2002). Uppväxtfamiljens roll har förändrats i och med att både familjen och den offentliga sektorn fått ta ett större ansvar för att överbygga ungdomars etableringsproblem på arbetsmarknaden (Rantakeisu 2002). Arbetsmarknadspolitiska program har framför allt riktats till unga och den normala sysselsättningen har ersatts av kortvariga sysselsättningsperioder (Aho \& Vehviläinen 1997; Schröder 2000). En del av de unga 
har definierats som marginaliserade och man har börjat vidta särskilda stödåtgärder och införa program för att integrera dem $i$ arbetslivet. I detta sammanhang träder speciella aktiveringsprojekt - och evalueringen av dem - in i bilden.

\section{Teoretisk referensram och metod}

\section{Levnadsloppet som narrativ resurs}

Med normalt levnadslopp avser vi den normalmodell för vuxenblivande och inträde i arbetslivet som kom fram i intervjuerna med de unga. Samtidigt visar modellen hur levnadsloppet utformas i växelverkan mellan strukturella villkor och individuella val (Levy 1996, 83-104). Levnadsloppet formas enligt mer eller mindre bestämda mönster. Levy talar om "standardlevnadslopp" eller "normalbiografier" (ibid.). Begreppet normalt levnadslopp hänvisar till den diskursiva världen: det är en kognitiv och tolkningsmässig resurs som styr det sätt på vilket människor organiserar sina erfarenheter och ger dem innebörder - och berättar om dem i en intervju. Normalbiografin byggs upp av ett institutionellt "manuskript" som avancerar från barndomen genom ungdomen till vuxenlivet. Individen förutsätts engagera sig i åldersbestämda uppgifter vilkas utförande i sin tur antas förutsätta bestämda egenskaper, kunskaper och färdigheter. Levnadsloppsmodellen används för identifiering och bedömning av händelser under olika skeden av livet; den laddar dem med innebörder. (Gubrium et al. 1994; Hoikkala 1993, 14-21.)
I konstruktionistisk levnadsloppsforskning undersöker man hur människor sorterar händelserna i sitt liv och hur de ger dem innebörder i relation till tiden. Levnadsloppsbegreppet är ett sätt att strukturera händelser och göra dem förståeliga. Levnadsloppet är ett slags vokabulär, en kombination av olika sätt att strukturera och representera erfarenheter i relation till tiden i situerad växelverkan - i detta fall i en forskningsintervju. Förändring är den centrala komponenten $\mathrm{i}$ ett levnadslopp; de förändringar som sker i livet blir föremål för tolkning. Typisk vokabulär är skede, kris, vändpunkt och mognad. Även uppfattningar om ålder ingår i vokabulären. (Gubrium et al. 1994, 2-41.)

När den unga berättar om sitt liv blir själva berättandet scener för livsbemästring, på vilka man behandlar det förflutnas relation till nutiden och nutidens relation till framtiden. Anni Vilkko (1997, 52, 94), skiljer med stöd av Labov och Waletzky mellan två olika funktioner i en berättelse: en refererande, som skildrar händelser, och en evaluerande, som bedömer betydelsen av det berättade. Berättelsen om det förgångna ställs i relation till nuet och till de innebörder den i nuet levande bedömande berättaren ger händelserna. De evaluerande ingredienserna ger enskilda händelser och kedjor av händelser sin plats i livstolkningen.

\section{Material och analys}

„Deras berättelser» som analyseras i denna artikel bygger på kvalitativa intervjuer med sammanlagt 25 unga i åldern 17-21 år, av 
vilka 14 är kvinnor och 11 män. Intervjupersonerna rekryterades utifrån sin barnskyddsbakgrund, så att en del har en bakgrund inom den öppna vården, en del inom barnskyddsinstitutioner, medan en del har erfarenhet av båda. De unga intervjuades $i$ två omgångar, med ungefär ett års mellanrum. I andra omgången nåddes 17 (11/6) av ungdomarna för en intervju. Genom att bygga upp intervjuerna som en kombination av tema- och livshistorieintervjuer fick vi in både en vertikal och en horisontell dimension i dem. Den horisontella dimensionen inriktar sig på relationen mellan olika livsområden i de ungas aktuella livssituation, medan den vertikala dimensionen uppmärksammar förändringar bakåt och framåt i tiden. Vi var speciellt uppmärksamma på hur de unga förankrade sig i arbetslivet och vilken HELSAs roll var i detta. $^{4}$

Förutom att uppmärksamma den narrativa dimensionen i intervjuerna har vi analyserat intervjuerna diskursivt. De erfarenheter de unga berättar om i intervjusamtalet filtreras genom deras vetskap om att ungdomar som är i kontakt med barnskyddet utgör en grupp som är föremål för myndigheternas speciella uppmärksamhet och om vilken det i samhället råder vissa uppfattningar. De intervjuade ungdomarna återspeglar därmed i sina berättelser om sina liv "vår» inställning till "dem" som en grupp med speciella förtecken. Analysen

4 Inom projektet utfördes också en kvantitativ undersökning där vi utredde effekterna av HELSA-projektet genom att mäta hur ungdomarna placerade sig i arbetslivet samt vilka förändringar de tyckte att hade inträffat i deras liv (se Julkunen, Strandell, Kangas 2000). tar sin utgångspunkt i hurudana identiteter eller sätt att bygga upp det egna jaget och dess förändring över tid som framkommer i intervjuerna. Begreppen identitet och jag syftar här på någonting som är socialt och föränderligt och som har sin bas i social växelverkan. Identiteter konstrueras i växelverkan med å ena sidan förställningar om hur den grupp de definieras in i är socialt konstruerad och å andra sidan en pågående interaktion med intervjuaren, som också kan associeras med denna diskurs (Gubrium \& Holstein 2001, 6-7; Sahlin 2001, 48).

Ett kännetecknande drag för vår samtid är enligt Jaber Gubrium och James Holstein (2001) att det offentliga livet i ökande omfattning erbjuder oss identiteter, dvs. modeller för hur vi skall förstå oss själva och vår situation. Vem vi är och vilka egenskaper och problem vi har har blivit en fråga för självhjälpsgrupper, sociala myndigheter och välfärdstjänster, psykiatrin, televisionen, pressen och internet. Samtidigt som vår tid mer än någonsin betonar det "egna» unika jaget blir våra personliga jag allt mera avprivatiserade och offentligt konstruerade.

Kännetecknande för dessa diskursiva identiteter är att de för det mesta är problemtyngda, ofta konstruerade i termer av "för mycket" eller "för lite». Vi förser oss med ett överflöd av problemidentiteter ("alkoholisten", "den misshandlade kvinnan «) för konstruktionen av våra jag. Problemidentiteterna skapar samtidigt sin motpol, det oproblematiska, normala jaget. I sina identitetskonstruktioner förhåller sig människor till dessa problemidentiteter, genom att övertyga sig om att de är "normala», och 
att de inte berörs av de problem som problemidentiteten målar upp (ibid., 9-11).

En sådan spänning mellan å ena sidan en normal identitet eller ett normalt levnadslopp och å andra sidan en problemidentitet är ett drag som starkt strukturerar intervjuerna. Föreställningen om hurudan en person är som är eller har varit i kontakt med barnskyddet kan betraktas som en problemidentitet, som de unga tvingas förhålla sig till för att kunna göra sig förstådda för intervjuaren. Vi blev därför intresserade av hur ungdomarna använder sin vetskap om vad som är normalt för att rama in sin berättelse samt hurudant det "normala" levnadslopp är som ungdomarna konstruerar som ram för sin berättelse och till vilket de relaterar sina upplevelser. Och var placerar den unga in sig själv som aktör?

Man kan naturligtvis ställa sig frågan om inte alla människor - oberoende av ålder och erfarenhetsbakgrund - relaterar sitt eget liv till en bild av ett normalt liv. I detta avseende är skillnaderna mellan barnskyddsungdomar och andra inte nödvändigtvis särskilt dramatiska. Det som gör just denna grupps uppfattning om det "normalau intressant är att de ser på det "normala" från "marginalen". I och med sin medvetenhet om den problemidentitet de tillskrivs har de inte lika lätt att avfärda den, att konstruera sig som motsatsen till den. De tvingas vara mera övertygande, och gör därigenom det normalas normativitet mera synlig och tillgänglig för analys. Det "normalau som ram för den egna berättelsen blir därmed mera tvingande än hos ungdomar i allmänhet.

Vi fäste uppmärksamhet vid ambivalensen i de ungas berättelser. Vi antog att ambivalensen i synnerhet har att göra med det "normalas" snävhet och dess påtvingande karaktär. Att sträva efter det normala upplevs ofta som belönande. Eftersom det är svårt att uppnå förträngs det samtidigt. Ju avlägsnare det normala upplevs vara, desto motstridigare gestaltar sig normativiteten. När man dessutom tar marginalitetsbegreppets politiska dimension med i betraktelserna, dvs. strävan att tvinga in alla medborgare i samma värdesystem (se Helne 1996, 297), blir ambivalensen ännu större. Om utslagning inte definieras utgående från integration, utan som en form för alternativ gemenskap, som ett sätt att lämna sig eller bli lämnad utanför samhällets normaliserande representationer, får marginaliteten som ett ibland önskat och kreativt tillstånd utrymme (ibid., 293-295). Vetskapen om de normaliserande representationerna och den samtidiga existensen av alternativa gemenskaper - i detta fall till exempel polare eller fritidssysselsättningar - producerar ambivalens, som de ungdomar vi har intervjuat behandlar som ett inslag i sina berättelser.

I analysen av intervjumaterialet har vi tagit fasta på spänningen mellan normalbiografi och problemidentitet. Vi har urskiljt tre olika typer av berättelser och identitetskonstruktioner, som har konstruerats i växelverkan mellan teori och närläsning av materialet. En enskild intervju representerar till sina huvuddrag en berättelsetyp, men kan samtidigt innehålla drag av en annan berättelsetyp. Några intervjuer har varit alltför otydliga när det gäller relationen mellan normalitet och problemidentitet för att kunna inplaceras. 


\section{Tre berättelsetyper}

\section{Från "slarver" till god medborgare}

En berättelsetyp som är relativt rikligt representerad i materialet är den förändringsbetonade: berättelsen om förändring från det sämre till det bättre. I den kan man tydligt urskilja förr-stadiet från nu- stadiet. Typiskt för berättelsen är en intrig som pekar framåt, enligt vilken livet handlar om att gå vidare, från det sämre till det bättre. Berättelserna innehåller relativt mycket bedömande uttalanden om händelser och deras innebörder.

Jody Miller och Barry Glassner (1997) har i sina intervjuer med gängungdomar noterat att ungdomar använder vissa narrativa redskap för att göra sig själva förstådda för personer som de antar att inte känner till deras värld. Ungdomarna förhåller sig till uppfattningar om det avvikande och det normala så att de antingen stärker våra förhandsuppfattningar eller utmanar dem genom att intyga att de i själva verket lever ett helt normalt och vanligt liv som vi kan känna igen oss i. De barnskyddsungdomar vi intervjuat använder ofta båda redskapen inom ramen för samma berättelse. Berättelsens början byggs ofta kring det som avviker från det normala. Men ju närmare nuet den unga kommer, desto mera förflyttar sig han eller hon i sin berättelse till en för "oss" bekant och igenkännlig värld.

Förr-stadiet förknippas med många slags "dåliga» företeelser, som våldsamt festande, hårt supande och/eller drogmissbruk. Man genomgick "förfärliga arbetslöshetsperioder", slöande och depressioner. Det började gå utför, och allt man orkade med var att sova långt in på eftermiddagen och knarka. Nerverna höll inte när allt gick åt skogen. Livet gick på tomgång, det var ett enda hängande, in och ut i jobb och utbildningar. Ifall situationen hemma tillspetsades och det uppstod problem med modern, och fadern ifall han fanns i bilden, växte svårigheterna ytterligare. Alternativt började det barka utför i det skede när den unga började lösgöra sig från hemmet och flyttade ut.

$\mathrm{Nu}$-stadiet återigen fylls av positiva händelser. De unga upplever att de nu är helt annorlunda och mycket nöjdare människor. Man har hittat en trevlig pojkvän och skapat ett ordentligt hem. Man har fått något att göra och lärt sig leva självständigt, vilket lett till ökat självförtroende, "...jag har liksom fät allt, livet har lugnat ner sig och jag har lämnat allt det gamla bakom mig". Nu-stadiet kan innebära att bli mamma, och få ett tryggt och ombonat liv. Allt går nu mycket bättre, livet går sin gilla gång och den unga är nöjd. "Jag har koll på livet, ekonomin är i skick och jag har arbete, hund och bostad. Jag har vänner som jag kan tala med." Nu-stadiet kännetecknas av att livet blivit lugnare, man tar ansvar, klarar av vardagen, blir van vid en regelbunden dygnsrytm samt är ekonomiskt självständig.

Mellan förr- och nu-stadiet inplaceras ofta en tydlig vändpunkt som förändrar händelsernas gång och deras innebörder. Det är kanske inte särskilt överraskande att arbete och studier, samt HELSA:s andel $i$ att få igång dem blir vändpunkten i berättelserna. Genom att arbeta och/eller studera blir man en "god medborgare", och HELSA:s uppgift är just att locka in ungdomarna på denna väg. 
Ungdomarna är också mycket medvetna om utbildningens betydelse som inkörsporten till ett normalt liv, där olika livsområden faller på plats. Denna medvetenhet strukturerar kraftigt berättelserna. Studier och yrkesutbildning blir de viktigaste vägarna till vuxenhet och självständighet. De fyller nu det utrymme som tidigare upptogs av "dåliga» vanor. De uppfattas som förändringens motor och för dem är man färdig att offra saker som tidigare har spelat en central roll i livet, t.ex. att fördriva tiden tillsammans med vänner och kompisar samt festande till sent på natten. Med hjälp av arbete och studier får man en fungerande dygnsrytm och regelbundenhet i sitt liv. Ungdomar som bor eller har bott på anstalt sammankopplar oftare än andra självständighet och livsförändring med att få bo självständigt.

När intervjuaren väcker diskussion om den ungas framtidsutsikter, förstärks lineariteten och även strävan till det normala i berättelserna. De unga bygger sitt liv enligt det normala levnadsloppets manuskript:

"Alltså att kanske familjen då är det viktigaste och sen förstås jobbet och sånt. Sånt som morsan och farsan gjorde tillsammans med oss när vi var barn, ett normalt familjeliv alltså» (småbarnsmamma).

"Men alltså, det sku vara toppen att bilda en egen familj... jag har bara det här att en familj borde man ha och man sku kunna gifta sig och då sku man ha en sån där egen grej som är hela tiden«.

"Jag hoppas att jag om fem år har stadens hyresbostad, körkort, bil och pojkvän, och jobb och studieplats".
Att få ett yrke, att komma in i arbetslivet och att hålla sig kvar där har första prioritet.

"Visst vill jag att jag har nåt yrke om fem år. ... Jag har beslutat att jag vill ha [en baby] medan jag ännu är ung, men först vill jag ändå ha nån utbildning o nåt arbete. "

„Arbetet känns bara på nåt sätt så viktigt att jag liksom inte orkar gå nånstans sent på kvällen. ... Jag känner att det är mycket viktigt för mig. Jag har liksom livet i ordning".

Detta är relativt ljusa berättelser om att lyckas, om tillförsikt och ökat självförtroende. Förr- och nu-stadierna skiljer sig tydligt från varandra och är i mycket varandras motsatser. Berättelserna utstrålar ordentlighet, sinnesfrid, vuxenblivande, självständighet, regelbundenhet, vanligt liv. Varför understryks det normala och vanliga i berättelserna? Varför är allting så ordentligt? Hos dessa unga tycks det normala levnadsloppet inte enbart vara en lös referensram som man kan använda eller låta bli att använda vid inramningen av sitt livs erfarenheter, utan en relativt tvingande "karriärstege, från vilken man inte tillåter sig avvikelser eller kritiskt avståndstagande. En delorsak till de ungas starka strävan efter det normala är säkert berättelsens lyssnare. Intervjuerna i undersökningen är ur de ungas synvinkel en del av HELSA-projektet; vi representerar alltså även som forskare samhällets normaliserande representationer. Det är inte heller särskilt överraskande att de ungdomar i vilkas berättelser det går att finna en förändringskurva från det sämre till det bättre oftare har en bakgrund 
i den öppna vården än vad deras andel $\mathrm{i}$ materialet skulle förutsätta. De representerar därmed barnskyddsungdomarnas "grädda» och är oftare flickor än pojkar.

\section{Den fragmentariska karriären som tillämpning av det normala}

När vi tittar på hur de intervjuade ungdomarnas liv - enligt deras egna utsagor - hittills har förlöpt, så försvinner en stor del av lineariteten. Endast få har stegat framåt stadigt och jämnt och förankrat sig tryggt $i$ arbetslivet med hjälp av en yrkesidentitet (se Lamminen 2000, 67-70). Det är betydligt vanligare med avbrott i karriären, varvid förankringen blir partiell och sårbar.

Typiskt för denna partiella förankring är att arbets- eller utbildningsperioder och perioder utan arbete eller utbildning alternerar med en viss regelbundenhet. Man jobbar eller utbildar sig ett par månader, sedan håller man en ledig period, och sedan orkar man bli intresserad av jobb och studier igen.

Det vore fel att säga att alternerandet mellan arbete och lediga perioder skulle vara planerat och avsiktligt. Lika litet är det något som ungdomarna bara slumpmässigt råkar ut för och vars hjälplösa offer de skulle vara. Alternerandet innehåller många slags element. För många ungdomar är ett normalt arbetsliv med åtta timmars arbetsdagar som börjar tidigt på morgonen för mycket begärt. De unga upplever att det inte blir någon tid över för annat liv. Andra livsområden som lika väl hör till det normala levnadsloppet drabbas: man orkar inte hålla hemmet i ordning, man har ingen tid för fritidsintressen eller för vänner och kompisar. Ett par månaders paus då och då återställer balansen mellan arbetet och resten av livet. Längre arbetslöshetsperioder än så börjar kännas påfrestande, medan korta arbetslöshetsperioder kan upplevas som välkomna avbrott i en alltför hektisk arbetsrytm. Arbetsfria perioder upplevs då inte nödvändigtvis som arbetslöshet, utan åtminstone $i$ viss mån som usemesterperioder«. Om pausen blir för lång börjar den dock till sina innebörder klarare att framstå som icke-önskad.

"Intervjuaren: Hurdan var den där tiden då du var arbetslös?

Marja: Öhmm. Det var egentligen riktigt roligt. Det sku vara idealiskt att jobba t.ex. bara varannan månad, då fär man mycket gjort hemma och man kan gå ut och träffa folk. Det är läskigt när man städar på jobbet och sen, när allt här hemma är $i$ en enda röra, när man bara inte orkar börja städa här hemma. Det var på nåt sätt en lättnad [att vara arbetslös]. Jag fick faktiskt vara $i$ fred då. Men sen till sist så började det ju... Innan jag jobbade på daghemmet så var jag ju ändå över ett halvt år arbetslös. Det började definitivt bli för mycket. Att $i$ helvete, finns det nu ingenting, och sen blev jag deppig så att jag int orka söka nåt jobb mera, o sen börja jag bara spela kort och sova dagarna i ända. Sånt där. Men det sku vara skönt att emellanät hälla en veckas pauser."

I Finland är arbetstiderna av tradition tämligen oflexibla. Till exempel deltidsarbete, som kunde underlätta de ungas hantering av vardagen, har i Finland alltid varit ett 
marginellt fenomen (Julkunen, Nätti 1999, 38 , 40). Inte ens kvinnorna har hos oss nämnvärt - till skillnad från många andra länder i Skandinavien och övriga Europa - brutit det enhetliga arbetstidsmönstret (ibid., 44). Inte heller de unga har alltså kunnat använda deltidsarbete som byggstenar för ett normalt liv. Det representerar inte det normala livet, och ungdomarna nämner det knappt som en möjlighet. Även om flexibiliteten har ökat efter att den nya arbetstidslagen godkändes år 1996 (ibid., 44), är den finländska arbetstidsmodellen fortfarande i hög grad en antingen-ellermodell: antingen är man heltidsarbetande eller så står man utanför arbetslivet; antingen arbetar man för mycket eller inte alls.

En fragmenterad yrkesbana kan ses som en form av flexibilitet som gör det lätttare att förena arbetet med resten av livet. För många ungdomar är det fråga om den första arbetsplatsen, som de spänner sig för av flera orsaker: klarar jag mig, orkar jag gå till arbetet tidigt på morgonen, vad tänker de andra om mig och hur förhåller de sig till mig? De har ännu inte fått rutin i att hålla en balans mellan arbetet och resten av livet. Anställningsförhållandenas kortvarighet utgör mera sällan ett problem för ungdomarna. De väntar sig inte ens att anställningarna nödvändigtvis skall vara långa (Lamminen 2000, 72-73). Hur väl en fragmenterad yrkesbana fungerar är i mångt och mycket beroende av hur de lediga perioderna mellan arbetsperioderna kan väljas och styras av ungdomarna själva, i vilken mån de kan inverka på när den lediga perioden börjar och speciellt när den slutar.
En fragmenterad yrkesbana tycks således kunna utgöra en fungerande "tillämpning« av det lineära, normala levnadsloppet. Med dess hjälp kan den unga bearbeta den ambivalens som hör ihop med det normalas snävhet och påtvingande karaktär. Det är ett sätt att förena deltagandet $i$ arbetslivet med de övriga livsområdena i ett balanserat liv - ett sätt som kommer nära det normala levnadsloppet. Katja Komonen (2001, 102-116, 241-245) har undersökt ungdomar som avbrutit sin yrkesutbildning och $i$ hennes tolkning ingår avbrotten som en del i byggandet av en rationell utbildningsbana. Att avbryta utbildningen visade sig ur den ungas synvinkel ofta vara en positiv lösning, som riktade utbildningsstigen i en bättre riktning. Sålunda representerade den åtminstone delvis ett förnuftigt och motiverat val. Komonen anser att avbrott alltför ensidigt har tolkats som misslyckanden.

Är en fragmenterad karriär då överhuvudtaget en avvikelse från det normala levnadsloppet? 1990-talets ändrade arbetsmarknad och arbetskraftspolitik har gjort avbrott vanligare än tidigare. Enligt Kari Nyyssölä och Sasu Pajala, som undersökt ungdomars arbets- och utbildningskarriärer (1994, 144, se även Komonen 2001) håller den finländska institutionaliserade övergången från utbildning till arbetsliv på att bli fragmenterad och instabil generellt, vilket tar sig uttryck i arbetslöshetsperioder, avbrutna utbildningar samt avsaknad av normala anställningsförhållanden. Åtminstone ett visst antal avbrott skulle i så fall representera ett helt vanligt levnadslopp. 


\section{Det normala som det ouppnåeliga}

En fragmenterad karriär fungerar inte på långt när alltid som en tillämpning av det normala. Ibland är arbets- eller utbildningsperioderna korta, medan de lediga perioderna däremellan blir desto längre. De lediga perioderna upplevs som obehagliga och problematiska, och de hotar hela livsbemästringen. Det är svårt att se dem som en betydelsefull del av vardagslivet "... när jag tycker att det är irriterande att bara ligga dagarna $i$ ända utan att göra nåt». Det är svårt att finna en balans mellan arbetet och livet i övrigt. Även arbetsuppgifterna upplevs ofta som alltför krävande eller motbjudande. Umgänget med arbetskamrater och överordnade orsakar problem då de unga upplever att man bollar med dem hit och dit och att de lätt blir utnyttjade. Det sliter på nerverna.

När det inte går att finna en balans mellan arbetet och resten av livet, fungerar arbete och utbildning inte heller som agenter i någon som helst förändring. I berättelserna finns i detta avseende inget "framåt och uppåt». I en del av berättelserna går det inte att finna någon riktig förändringskurva med tydligt framträdande förr- och nu-stadier och vändpunkter. Ett typiskt drag är däremot diskontinuitet och slumpmässighet. Berättelserna saknar en framåtbärande intrig som skulle placera in de enskilda händelserna i ett vidare sammanhang och definiera deras innebörder i relation till varandra. Saker bara inträffar, mer eller mindre oförutsebart och okontrollerat. Man tror på slumpen, att det alltid går att hitta någon utväg. Man orkar inte studera eller skaffa sig ett yrke, men är redo att ligga i och jobba. Att klara sig i livet bygger på hårt arbete. Man hittar alltid nånting - eller så klarar man sig utan. Livet finns i nuet.

Istället för att fungera som en förändringsagent blir utbildningen i dessa fall en verklig stötesten. Utbildningens karaktär av "nålsöga» och obligatorium (se Nyyssölä 1999, 175-177) kommer hos de utbildningsmotsträviga fram ännu tydligare än hos dem som producerar förändringsberättelser. Hos dessa verkar allt tal om utbildning mer eller mindre håglöst och påtvingat.

"Int är jag så värst intresserad av att sätta mig på skolbänken, men är det så så måste man väl.... Int vill jag bo nånstans på gatan och vara helt utan pengar. Man måst ju skaffa sig nait yrke».

"Nej alltså.. Jag menar faktiskt på allvar att jag borde studera liksom...nånting alltså. Då skulle det kanske senare bli nånting av nånting. Eller jag vet faktiskt int alls just nu vad jag egentligen borde göra, att ett läroavtal kunde kanske vara nåt... int vet jag. Det är kanske så att nåt slags arbete är liksom jätteviktigt just för mig...Eller nån utbildning liksom sådär..."

Det är inte alls ovanligt att berättelser i vilka det inte går att urskilja en klar förändringsintrig kopplad till arbete och studier framställs av sådana ungdomar som ännu bor kvar eller har bott i barnskyddsanstalter. De berättas också oftare av pojkar än flickor. Ibland kan boendet bli ett tema som strukturerar hela intervjun. Boendesituationen, dess problem och de förhoppningar som ställts på en förändring i den intar en 
central plats i berättelsen. Missnöjet med den nuvarande livssituationen förknippas i mångt med boendet på anstalt. Förändringen av boendesituationen blir den motor med vars hjälp hela livssituationen - förhoppningsvis - skall bli mera tillfredsställande. Däremot hamnar den förändringspotential som ligger $\mathrm{i}$ arbete och utbildning $\mathrm{i}$ bakgrunden $\mathrm{i}$ berättelserna.

En hypotes kunde vara att boendet placeras i berättelsernas centrum för att frigörelsen från anstaltsboende är en betydligt mera omfattande process än frigörelsen från ett vanligt hem - må så vara att det kan ha varit problem i familjen. Anstaltsboende representerar i vårt av kärnfamiljsideologi impregnerade samhälle en uppväxtmiljö som avviker från normala. Att flytta från anstalt till egen bostad eller servicebostad är ett större språng mot det normala än att flytta från den egna barndomsfamiljen till självständigt boende. Denna problematik bearbetas i berättelserna mera ingående än flyttandet från barndomsfamiljen.

Vissa ungdomars livserfarenheter är så fjärran från det "normalau att det inom ramen för det normala levnadsloppets manuskript inte går att berätta om de egna erfarenheterna. Man orkar inte riktigt tro på en förändring, och man har inte tillräckligt med byggstenar för att konstruera ett levnadslopp i normala fåror. Ungdomarna har i sin bakgrund svårare upplevelser än förändringsberättarna har, såsom besvärliga familjeförhållanden, alkoholiserade föräldrar, förälders död, omhändertagande, vantrivsel i barnhemmet, skolsvårigheter. Klyftan mellan det man upplevt och det man borde eftersträva har blivit för stor.

Också de berättelser i vilka det inte går att finna en förändringsintrig med tillhörande vändpunkter kan tolkas vara berättade $\mathrm{i}$ förhållande till det normala levnadsloppet. I extremfall gör man dem till förändringsberättelsens och det »normalau levnadsloppets motsats: man blir inte vuxen, man stadgar sig inte, man bryr sig inte om, man vill inte ha någon förändring. Jobbena är "skitjobb", arbetslösheten är att „bara slöa». Den unga väntar sig inte ens att livssituationen skall förändras när han eller hon flyttar från ungdomshemmet till en stödbostad "utom att där int finns nån som kollar på en«. Det är bara andra som tycker att knarket är ett problem. Här finns ingen lust att utbilda sig, och framtiden orkar man inte tänka på. På frågan om vad som är det viktigaste i livet för tillfället kan svaret bli:

"Vet int... att supa kanske ... Det är viktigt att vila. Att äta och andas. ...Kompisar att supa med och sex."

"Jag lever bara en dag $i$ sänder...Jag lever enligt den principen att vi är här bara en gång och en gång lämnar vi alltsammans. Det gör detsamma på vilket sätt man är här. [Efter fem år?] Jag sover och snarkar. Int kan ja svara på det där."

Likgiltigheten kan även vara ett medvetet distanstagande från det normala. Oviljan att delta i skapandet av en berättelse i intervjusituationen och den knappa förekomsten av utvärderande element $i$ berättelsen tyder även på att man är medveten om att berättelsen blir "fel«, att allt borde vara på ett annat sätt och livet borde förlöpa annorlunda. 


\section{Diskussion}

Barnskyddsungdomarnas berättelser synliggör på ett intressant sätt de strukturella villkoren för olika val. Utbildningens centrala ställning som inkörsporten till ett "normalt» vuxenliv utgör berättelsernas röda tråd, både hos dem som är motiverade att söka sig till utbildning och som finner sin plats i utbildningsdjungeln, och hos dem som saknar motivation för utbildning eller förmåga att klara av den. I detta avseende skiljer sig en barnskyddsungdoms berättelse knappast särskilt mycket från många andra ungdomars berättelser i dagens Finland. Även om det inom ramen för denna artikel inte är möjligt att göra jämförelser med andra ungdomar, kan man ändå anta att denna grupps särdrag utgörs av en stark strävan att skriva in sig i det "normala" vuxenlivet samt av en avsaknad av val som utmanar rådande värderingar. De positiva alternativen är få; det walternativa» representeras närmast av alkohol-, drog-, arbetslöshets- och mentala problem.

I artikeln har tre typer av berättelser analyserats. Den förändringsbetonade berättelsen var relativt rikligt representerad i materialet. Typiska drag i denna berättelse var en intrig som pekade framåt och uppåt, från det sämre till det bättre. Det "normala" levnadsloppet utgjorde inte enbart en lös referensram för inramningen av sitt livs erfarenheter, utan en relativt tvingande "karriärstege«, från vilken man inte tillät sig avvikelser eller kritiskt avståndstagande. Den andra berättelsetypen var mera fragmentarisk. Avbrott av olika slag framträdde här som det centrala temat som strukturerade berättelserna. Ett lapptäcksaktigt kombinerande av arbete, studier och lediga perioder tycks ha blivit ett vanligare sätt än tidigare att orientera sig bland alla de möjligheter som står till buds i ett allt mera komplext samhälle.

Den tredje berättelsetypen saknade en framåtbärande intrig. Den kännetecknades av diskontinuitet, oförutsägbarhet och okontrollerbarhet. När den unga i ett sådant sammanhang önskar "bara man sku ha ett sånt där normalt liv", får orden sin innebörd i en annorlunda kontext än i förändringsberättelserna. Det är mera fråga om orealistiska förhoppningar och drömmar än inskrivning av egna erfarenheter i det normala levnadsloppsmönstret.

Analysen av de tre berättelsetyperna väcker frågan om huruvida det "normala" kunde göras mindre snävt, tillåtande en större variation i sättet att »bli vuxen«. Som forskare upplever vi ett behov att skjuta tyngdpunkten i diskussionen om ungdomar „i riskzonen" från det problematiska i att inte klara av att hålla sig inom det »normalas« gränser till ett ifrågasättande av själva gränserna. Den ökande fragmenteringen återspeglar samhällets förändring och i synnerhet utbildningens förändrade ställning. Som tidigare konstaterades håller den institutionaliserade övergången från utbildning till arbetsliv att generellt bli mera fragmenterad och instabil, en utvecklingstendens som borde höja toleransnivån för alternativa sätt att ta sig fram. Olika sätt att institutionalisera fragmenteringen och bygga in den i en "normal" livsbana kunde hjälpa ungdomarna att finna sin egen plats i samhället och öka deras möjligheter watt vara brapånånting". 


\section{Litteratur}

Aho, Simo, Vehviläinen, Jukka (1997) Keppi ja porkkana. Tutkimus alle 20 -vuotiaita aktivoivan työvoimapoliittisen uudistuksen vaikutuksista ja koulutuksen ulkopuolelle jäävistä nuorista. ESR-julkaisut No 3, Helsingfors: Arbetsministeriet.

Bynner, John (1997) Agenda for youth research in the next century: a British perspective. YOUNG5(4); 34-39.

Fauske, Hans (1996) Changing youth: transitions to adulthood in Norway. YOUNG 4 (1);47-62.

Gubrium, Jaber, Holstein, James, Buckholdt, David (1994) Constructing the life course. New York: General Hall.

Gubrium, Jaber, Holstein, James (2001) Introduction: Trying Times, Troubles Selves. I skriften: Jaber Gubrium och James Holstein (red.) Institutional Selves. Troubled Identities in a Postmodern World. Oxford: Oxford University Press, $1-20$.

Griffin, Christine (1997) Representations of the Young. I skriften: Jeremy Roche och Stanley Tucker (red.): Youth in Society. Contemporary Theory, Policy and Practice. London: SAGE, 1725.

Helne, Tuula (1994) „Erään muodin tarina: 1980luvun suomalaisesta syrjäytymiskeskustelusta". I skriften: Matti Heikkilä och Kari Vähätalo (red.) Huono-osaisuus ja hyvinvointivaltion muиtos. Helsinki: Gaudeamus.

Helne, Tuula (1996)»Uudet uljaat uusheimot - Martine Xiberras ranskalaisen syrjäytymisteorian edustaja». JANUS 4(3), 292-299.

Hoikkala, Tommi (1993) Katoaako kasvatus, himmeneeköaikuisuus? Aikuistumisen puhe ja kulttuurimallit. Helsinki: Gaudeamus.

Julkunen, Ilse, Strandell, Harriet ja Kangas, Heidi (red.) (2000) „Kunnon elämä... olisi hyvä jossain «. Helsinki: SSKH Skrifter Nr 12.

Julkunen, Raija, Nätti, Jouko (1999) The Modernization of Working Times. Flexibility and Work Sharing in Finland. Jyväskylä: SoPhi University of Jyväskylä.
Komonen, Katja (2001) Koulutusyhteiskunnan marginaalissa? Ammatillisen koulutuksen keskeyttäneiden nuorten yhteiskunnallinen osallisuus. Joensuu: Joensuun yliopiston yhteiskuntatieteellisiä julkaisuja N:o 47.

Lamminen, Katri (2000) „Osittainen ankkuroituminen väylänä työelämään?»I skriften Ilse Julkunen, Harriet Strandell, Heidi Kangas (red.) „Kunnon elämä... olisi hyvä jossain". Helsinki: SSKH Skrifter Nr 12, 62-97.

Levy, René(1996) »Toward a Theory of Life Course Institutionalization" I skriften: A. Weymann ja W.R. Heinz (red.) Society and Biography. Interrelationships between Social Structure, Institutions and the Life Course. Deutscher Studien Verlag. Weinheim 1996, 83-104.

Miller, Jody, Glassner, Barry (1997) "The »Inside» and the "Outside». Finding Realities in Interviewsu. I skriften: David Silverman (red.) Qualitative Research. Theory, Method and Practice. London: SAGE.

Nyyssölä, Kari (1999) „Koulutuksesta työelämään siirtymisen murros ja huono-osaisuus». Yhteiskuntapolitiikka 64 (2), 169-181.

Nyyssölä, Kari, Pajala, Sasu (1999) Nuorten työura. Koulutuksesta työelämään siirtyminen ja huonoosaisuus. Helsinki: Gaudeamus.

Puuronen, Vesa (1997) Johdatus nuorisotutkimukseen. Jyväskylä: Vastapaino.

Rantakeisu, Ulla (2002) I arbetsmarknadens utkant - om långtidsarbetslösa ungdomars förhållningssätt till sin situation. Socialvetenskaplig Tidskrift 9 (4); 288-307.

Sahlin, Ingrid (2001) "Hemlösa» i intervjuer: myndighetsdiskurs och motdiskurs. Sosiologi i dag, 31 (4), 47-71.

Schröder, Lena (2000) Ungdomsarbetslösheten i ett internationellt perspektiv. Stockholm: Institutet för social forskning.

Swärd, Hans (1999) Att forska om utsatta. Socialvetenskaplig Tidskrift, 2; 173-180.

Vilkko, Anni (1997) Omaelämäkerta kohtaamispaikkana. Naisen elämän kerronta ja luenta. 
Helsinki: Suomalaisen Kirjallisuuden Seura. Walther, A, Stauber B (eds) (2002) Misleading Trajectories. Integration policies for young adults in Europe. Publications of the European Group for Integrated Social Research. Oplade Leske + Budrich.

Wyn, Johanna, White, Rob (1997) Rethinking

Youth. SAGE Publications.

\section{Summary}

\section{The attraction of normality-narratives from the margins}

The discourse on marginalization has penetrated the public debate. But how do young people who have been defined as marginalized interpret their situation? This article analyses young people's narratives to ascertain how they construct their identity. It is particularly the tension between normal life and a problem identity that is in focus in our analysis. Three different narratives could be found: (1) from a wastrel to a good citizen; (2) the fragmented career; (3) the unattainable normal life. The analysis of these narratives poses the question whether the "normal" could be made less narrow, so that it would allow a greater variety of ways to grow up. Different ways of institutionalizing the fragmentary elements and integrating them into a normal life course might help young people to find their place in society and increase their possibilities to "be good at something". 